\title{
Axial Spondyloarthritis in Inflammatory Bowel Diseases
}

\author{
Hana $\mathrm{S}^{1,2 *}$, Asma $\mathrm{B}^{1,3}$, Lamine $\mathrm{H}^{1,4}$, Aida $\mathrm{B}^{1,2}$, Rawdha $\mathrm{T}^{1,5}$ and \\ Msaddak A1,4
}

${ }^{1}$ University of Tunis El Manar, Tunis Medecine Faculty, Tunisia

${ }^{2}$ Department of Internal Medicine, Maamouri Hospital, Tunisia

${ }^{3}$ Department of Clinical Laboratory, Maamouri Hospital, Tunisia

\section{Editorial \\ Volume 1 Issue 3}

Received Date: October 13, 2017

Published Date: October 27, 2017

DOI: $10.23880 /$ mjccs- 16000115

${ }^{4}$ Department of Gastroenterology, Maamouri Hospital, Tunisia

${ }^{5}$ Department of Rheumatology, Charles Nicolle Hospital, Tunisia

*Corresponding author: Hana Sahli, Maamouri Hospital, 8000, Nabeul, Tunisia, Tel: +21672100500; E-mail: sahlihana@hotmail.fr

\section{Editorial}

Rheumatic manifestations are described in 25 to $30 \%$ of patients with IBD and represents the most frequent extra intestinal manifestation [1,2]. The association between ankylosing spondylitis and IBD was recognized as non-fortuitous since 1960 [3]. The frequency of axial spondyloarthritis (AS) is very variable [4]. This frequency depends to the study design with increased frequency in prospective studies (Table 1).

\begin{tabular}{|c|c|c|c|c|}
\hline Authors & Study type & Year & $\mathbf{N}$ & $\%$ \\
\hline Protzer, et al. [5] & Prospective & 1996 & 521 & 26.8 \\
\hline Orchard, et al. [6] & Retrospective & 1998 & 1459 & 2.1 \\
\hline De Vlam, et al. [7] & Prospective & 2000 & 103 & 10 \\
\hline Salvarani, et al. [8] & Cohort & 2001 & 160 & 3.1 \\
\hline Palm, et al. [9] & Cohort & 2002 & 654 & 3.7 \\
\hline Turkcapar, et al. [10] & Prospective & 2006 & 162 & 9.9 \\
\hline Lanna, et al. [11] & Prospective & 2008 & 130 & 6,2 \\
\hline Saadallaoui, et al. [12] & Prospective & 2009 & 50 & 26 \\
\hline Titsaoui, et al. [13] & Retrospective & 2012 & 316 & 20.6 \\
\hline Ditisheim, et al. [14] & Cohort & 2015 & 2353 & 2 \\
\hline
\end{tabular}

$\%$ : percentage; $\mathrm{N}$ : number of patients

Table 1: Frequency of axial spondyloarthritis in literature.

The frequency depends also on the imaging technique used. Indeed, it was between 3 and 11\% if the X-Ray was used and about $30 \%$ if the CT scan was performed [5]. In the studies of Master et al. and Davis et al., a sacroiliitis has been found in $50 \%$ of cases in bone scintigraphy $[6,7]$. Moreover, the frequency of AS depends on patient's criteria selection. The AS was observed more frequently when European Spondylarthropathy Study Group (ESSG) criteria were used and less frequently when modified New York criteria were used [8-11, 12,13]. Regarding risk factor for AS, Saadallaoui Ben Hamida, et al. [12], found that age older than 35 years old is a risk factor for AS with 


\section{Medical Journal of Clinical Trials \& Case Studies}

a relative risk of 5.8. Several studies didn't prove sex as risk factor $[12,14]$. Correlation between smoking and rheumatic manifestations of IBD had been discussed with contradictory results [15]. The impact of intestinal disease on risk for AS showed different conclusions. Indeed, the intestinal extension had a positive impact in the study performed by Saadallaoui Ben Hamida, et al. [12] and no impact in the study performed by Mester, et al. [6]. The high disease activity was associated with higher frequency of rheumatic manifestations only with crohn disease [16]. Few studies had discussed the impact of therapeutics on occurring AS. Moreover, elevated inflammatory blood tests were not considered as predictive factors for AS [12].

\section{Conclusion}

We recommend systematic checking of AS by a clinical exam and systematic radiological assessment for all patients with IBD and long-term follow-up of patients to detect signs of AS.

\section{References}

1. Puéchal X, Dernis E (2005)Manifestations articulaires des affections intestinales. Encyl Med Chir. (Elsevier Masson, Paris), Rhumatologie Orthopédie14-242-A-10, 10p.

2. Caprilli R, Gassull MA, Escher JC, Moser G, Munkholm P, et al. (2006) European evidence based consensus on the diagnosis and management of Crohn's disease: special situations. Gut 55 (Suppl 1): i36-i58.

3. Acheson ED (1960) An association between ulcerative colitis, regional enteritis, and ankylosing spondylitis. Q J Med 29: 489-499.

4. Fornaciari G, Salvarani C, Beltrami M, Macchioni P, Stockbrügger RW, et al. (2001) Musculoskeletal manifestations in inflammatory bowel disease. Can J Gastroenterol 15(6): 399-403.

5. Scott WW Jr, Fishman EK, Kuhlman JE, Caskey CI, O'Brien JJ, et al. (1990) Computed tomography evaluation of the sacroiliac joints in Crohn disease. Skeletal Radiol 19(3): 207-210.

6. Mester AR, Mako EK, Karlinger K, Györke T, Tarján $\mathrm{Z}$, et al. (2000) Enteropathic arthritis in the sacroiliac joint. Imaging and differential diagnosis. Eur J Radiol 35(3): 199-208.
7. Davis P, Thomson AB, Lentle BC (1978) Quantitative sacroiliac scintigraphy in patients with Crohn's disease. Arthritis Rheum 21(2): 234-237.

8. Orchard T, Wordsworth B, Jewell D (1998) Peripheral arthropathies in inflammatory bowel disease: their articular distribution and natural history. Gut 42(3): 387-391.

9. De Vlam K, Mielants H, Cuvelier C, De Keyser F, Veys EM, et al. (2000) Spondyloarthropathy is underestimated in inflammatory bowel disease: prevalence and HLA association. J Rheumatol 27(12): 2860-2865.

10. Salvarani C, Vlachonikolis IG, Van Der Heijde DM, Fornaciari G, Macchioni P, et al. (2001) Musculoskeletal manifestations in a populationbased cohort of inflammatory bowel disease patients. Scand J Gastroenterol 36(12): 1307-1313.

11. Palm O, Moum B, Ongre A, Gran GT (2002) Prevalence of ankylosing spondylitis and other spondyloarthropathies among patients with inflammatory bowel disease: a population study (the IBSEN study). J Rheumatol 29(3): 511-515.

12. Saadallaoui Ben Hamida K, Dougui MH, Ksontini I, Ben Yaghéléne L, Bouhaouala MH (2009) Prévalence des manifestations axiales au cours des maladies inflammatoires chroniques de l'intestin : À propos d'une étude prospective de 50 cas. Tunis Med 87(6): 386-390.

13. Manass M, Janani S, Mkinsi O (2007) Manifestations articulaires des maladies inflammatoires chroniques de l'intestin: à propos de 264 cas. Rev Rhum 74(5): 532.

14. Edmunds L, Elswood J, Kennedy LG, Galin A (1991) Primary ankylosing spondylitis, psoriatic and enteropathic spondyloarthropathy: a controlled analysis. J Rheumatol 18(5): 696-698.

15. Severs M, Van Erp SJH, van der Valk ME, Mangen MJ, Fidder HH, et al. (2016) Smoking is Associated With Extra-intestinal Manifestations in Inflammatory Bowel Disease. J Crohns Colitis 10(4): 455-461.

16. Ditisheim S, Fournier N, Juillerat P, Pittet V, Michetti $P$, et al. (2015) Inflammatory Articular Disease in Patients with Inflammatory Bowel Disease: Result 


\section{Medical Journal of Clinical Trials \& Case Studies}

of the Swiss IBD Cohort Study. Inflamm Bowel Dis 21(11): 2598-2604.

17. Protzer U, Duchmann R, Höhler T, Hitzler W, Ewe K, Wanitschke R, et al. (1996) [Enteropathic spondylarthritis in chronic inflammatory bowel diseases: prevalence, manifestation pattern and HLA association]. Med Klin (Munich) 91(6): 330335.

18. Turkcapar N, Tourner M, Soykan I, Aydintug OT, Cetinkaya $\mathrm{H}$, et al. (2006) The prevalence of extra intestinal manifestations and HLA association in patients with inflammatory bowel disease. Rheumatol Int 26(7): 663-668.
19. Lanna CC, Ferrari Mde L, Rocha SL, Nascimento E, de Carvalho MA, et al. (2008) A cross-sectional study of 130 Brazilian patients with Crohn's disease and ulcerative colitis: analysis of articular and ophthalmologic manifestations. Clin Rheumatol 27(4): 503-509.

20. Titsaoui D, Oukas I, Guendouzi T, Djedel T (2013) Manifestations extradigestives au cours des maladies inflammatoires chroniques de l'intestin : étude d'une série algérienne. Rev Med Intern 34: A160. 